\title{
Tři setkání s Jiřinou Popelovou
}

\section{Three encounters with Jiřina Popelová}

\author{
Jan Zouhar
}

\begin{abstract}
Abstrakt
Stat' rekapituluje život a hlavní práce Jiřiny Popelové, významné české filozofky 20. století. Hlavní pozornost věnuje třem sborníkưm, které vyšly k její poctě - Sborník k šedesátým narozeninám Jiřiny Popelové (1964), Jiřina Popelová, filozofka a učitelka filozofie (1984) a Filosofka Jiřina Popelová (2005). Podrobněji jsou připomenuty statě M. Sobotky, R. Kalivody, J. Peškové, P. Flosse a J. Gabriela. Ukazují př́nos J. Popelové pro filozofii dějin, komeniologii, etiku, filozofii kultury a historiografii evropské a české filozofie.
\end{abstract}

\section{Klíčová slova}

Jiřina Popelová, česká filozofie, sborníky, pocta J. Popelové

\begin{abstract}
The paper recapitulates the life and work of Jiřina Popelová, a major Czech philosopher of the 20th century. Attention is paid to three collections of papers published in her honour Sborník k šedesátým narozeninám Jiřiny Popelové (A Collection of Papers to Celebrate the 60th birthday of Jiřina Popelová) (1964), Jiřina Popelová, filozofka a učitelka filozofie (Jiřina Popelová, a philosopher and a teacher of philosophy) (1984) and Filosofka Jiřina Popelová (The Philosopher Jiřina Popelová) (2005). Closer attention is paid to the papers by M. Sobotka, R. Kalivoda, J. Pešková, P. Floss and J. Gabriel. These focus on J. Popelová's contribution to the philosophy of history, Comenius studies, ethics, philosophy of culture and the historiography of European and Czech Philosophy.
\end{abstract}

\section{Keywords}

Jiřina Popelová, Czech philosophy, proceedings, homage to J. Popelová

Příspěvek vznikl jako součást řešení projektu GA ČR Ženy v české filozofii a vědě (GA17-06697S). 
Setkání s Jiřinou Popelovou nám zprostředkují tři sborníky, které vyšly k jejím životním jubileím a výročím postupně v letech 1964, 1984 a 2005. Všechny se vzácně shodují v kladném hodnocení práce a působení Jiřiny Popelové, přestože každý z nich vyšel v jiné společenské situaci.

Jiřina Popelová (1904-1985) byla přední českou filozofkou 2. poloviny 20. století. Po maturitě na vinohradském gymnáziu studovala (1923-28) na FF UK filozofii a klasickou filologii. V r. 1929 obhájila na FF UK doktorskou dizertaci Quo modo Lucretius Epicuri de natura deorum doctrinam explicaverit. Učila na gymnáziích (Strážnice, Čáslav, Česká Třebová, Kralupy, Praha). Na začátku třicátých let byla krátce vdaná za filozofa Ladislava Janotu. Absolvovala studijní pobyt v Itálii (1932-34, s doktorátem na filozofické fakultě římské univerzity La Sapienza). Zde se také seznámila s akademickým sochařem Karlem Otáhalem, za kterého se po návratu do vlasti provdala. Po válce se v r. 1946 habilitovala na FF MU prací Tři studie z filozofie dějin a v roce 1947 byla jmenována mimořádnou, 1948 řádnou profesorkou filozofie na Pedagogické fakultě UK. V roce 1948 se na obnovené olomoucké univerzitě stala děkankou Pedagogické fakulty a v letech 1949-53 rektorkou Palackého univerzity v Olomouci. Od r. 1953 přednášela dějiny filozofie a etiku na FF UK.

K jejím nejvýznamnějším předválečným publikacím patří Poznáni kulturni skutečnosti (1936) a Tři studie z filozofie dějin (napsány 1945, vyšly 1947). První studie je pojata jako „úvod k noetice a metodologii kulturních věd“ a jedná o filozoficko-dějinném myšlení Řeků a Římanů, druhá je o historickém relativismu a možnosti jeho překonání a třetí o pojetí času v historii. Spojovacími články mezi zmíněnými knihami byly práce Dějiny a hodnoty (1941) a Pravda a jistoty (1942).

Po válce ocenila marxistickou filozofii (a marxismus vůbec) v brožuře $S o$ cialistický světový názor (1946). V knize K filozofické problematice Marxova Kapitálu (1954) mj. upozornila na filozofický a metodologický dosah Marxových Ekonomicko-filozofických rukopisů. Od poloviny 50. let se zabývala především dějinami české a evropské filozofie, zvláště J. A. Komenským, a etikou. V knize J. A. Komenského cesta $k$ Všenápravě (1958) a v monografii Filozofia J. A. Komenského (Bratislava 1985) ukázala, že Komenského filozofické a náboženské názory jsou základem jeho další činnosti teoretické i praktické. V roce 1958 jí byl na základě obhajoby práce Filozofické a společenské názory J. A. Komenského udělen na Lomonosovově univerzitě v Moskvě titul doktorky filozofických věd (DrSc.). „Filozofické schizma“ novodobé filozofie - spor jejího scientistického a iracionalistického proudu - prozkoumala v práci Rozpad klasické filozofie (1968). Jako etička chtěla budovat etiku vyplývající z vnitřní logiky 
filozofie, úzce spjatou s obecnou axiologií. Její Etika (1962), někdy mylně uváděná jako spis k „velkému doktorátu“ na Lomonosově univerzitě v Moskvě, je zaměřena k historii etiky i k současné mravní problematice, Étos a práce (1981) k etice povolání a Problém norem (1981) spojuje výklad mravních norem s celkovou analýzou normotvorné činnosti. Jako úvod do filozofie pojala knížku Zrozeni filozofie (1977). ${ }^{1}$

V roce 1964 uspořádal Milan Sobotka Sbornik $k$ šedesátým narozeninám prof. PhDr. Jiřiny Popelové, který pod tímto názvem vyšel na Karlově univerzitě v edici Acta Universitatis Carolinae. Philosophica et Historica. Jiřině Popelové je věnována první část sborníku. Nad jejím filozofickým dílem se zde zamýšlí Milan Sobotka, nad komeniologickým dílem Robert Kalivoda, třetí stat tohoto oddílu Podíl Jiřiny Popelové na rozvoji našich pedagogických věd a naší školy napsal Ervín Koukal. Další oddíly sborníku (Z historického materialismu, $\mathrm{Z}$ dějin filozofie a $\mathrm{K}$ filozofické problematice kulturních dějin) sledují jiná témata. Cenný je soupis prací Jiřiny Popelové, který sestavil Ladislav Menzel (s. 183-194).

Milan Sobotka se zamýšlí i nad prací Jiřiny Popelové $K$ filozofické problematice Marxova Kapitálu (1954). Připomíná, že Popelová rozšírila významně tehdejší rámec výkladu Marxovy filozofie, především v kapitole o Marxových Ekonomicko-filozofických rukopisech, „díle tehdy téměř proskribovaném“, protože „právě kniha Popelové zprostředkovala první znalost problematiky lidské podstaty, jejího zcizování do věcí a její deformace v zcizeném světě“.?

Stat Roberta Kalivody sleduje koncepci českosti a světovosti Komenského filozofie v díle Jiřiny Popelové. Popelová podle něho „překonává ,folklorní pojetí vztahu národních a světových hodnot tím, že specifické ,české hodnoty jsou zde pochopeny jako ony sociální, kulturní a ideové hodnoty, které vznikají organicky a zákonitě v sociálním organismu národa, mají však obecný dosah, obecnou platnost, fixuje se v nich úsilí ,obecného člověka' o pokrok celého lidstva. V těchto ,kosmopolitních“ hodnotách není nic ,bytostně národního“ - v tom však právě vytvářeji velikost národa, který je přivedl k životu."3 Kalivodovi se zdá mimořádně důležitý projev přesahu, „který je skryt ve výkladu českosti a světovosti Komenského, obsaženém v jejím velkém díle“. 4

1 Srov. Jiří Gabriel, Jiřina Popelová, in: J. Gabriel et al. (eds.), Slovnik českých filozofi̊, Brno: Masarykova univerzita, 1998.

2 Milan Sobotka, O filosofickém díle Jiřiny Popelové, in Sbornik k šedesátým narozeninám prof. PhDr. Jiriny Popelové, Praha: Univerzita Karlova 1964, s. 11.

3 Robert Kalivoda, Několik úvah nad komeniologickým dílem Jiřiny Popelové, in tamtéž, s. 21.

4 Tamtéž, s. 22. 
Další dva sborníky shrnují příspěvky ze dvou konferencí. Ta první se konala pod názvem Jiřina Popelová: filozofka a učitelka filozofie v roce 1984 v Brně na katedře filozofie Filozofické fakulty z iniciativy Jiř́iho Gabriela a byla věnována životu a dílu Jiřiny Popelové. Druhou konferenci v roce 2004 uspořádala v Praze z podnětu Evy Foglarové Filozofická fakulta Univerzity Karlovy ke 100. výročí narození Jiřiny Popelové.

Sborník z brněnské konference je rozdělen do oddílů, které sledují jednotlivé oblasti tvůrčí činnosti Jiřiny Popelové: filozofie dějin, česká filozofie, evropská filozofie, etika, umění a estetika.

Studie k filozofii dějin vycházejí z práce Tři studie z filozofie dějin, kterou Popelová napsala během 2. světové války a která vyšla až v roce 1947. První studie se věnuje filozofii dějin Řeků a Římanů. Popelová ji charakterizuje jako zárodek historického myšlení. Druhá studie se zabývá historickým relativismem.

Relativita historické fakticity i její reflexe byla v době druhé světové války otázkou klíčovou a implikovala znovu tematiku smyslu dějin. ${ }^{5}$

Relativita historické fakticity znamená, že se historický fakt znovu nově konstituuje v nových podmínkách a v nových dimenzích skutečnosti. Současně však usilujeme o stabilitu historických hodnot jako orientačních bodů při rozhodování. Třetí studie je věnována problematice času a časovosti a autorka zde klade především otázky, zejména otázku kontinuity a diskontinuity a otázku historického času, který není časem jednotným, protože každá vrstva historického dění má svůj vlastní čas, vlastní vývojový rytmus. ${ }^{6}$

Největší počet statí je v brněnském sborníku věnován problematice české filozofie v díle Jiřiny Popelové. Už jsme ukázali, jak Jiřina Popelová významně přispěla k rozvoji komeniologie. Její aktivitu v tomto směru hodnotili Olga Loužilová a Pavel Floss. Připomínají práci Popelové Jana Ámose Komenského cesta $k$ Všenápravě z roku 1958. Komenský v podání Popelové ,je hledající člověk, v jehož díle se zauzlila česká kultura a filozofie předbělohorské doby. Dědic velkých ideálů husitského lidu, jeho touhy po spravedlivém uspořádání tohoto světa. Současník a realizátor nejpokročilejších názorů na člověka

5 Jaroslava Pešková, Problém filozofie dějin v díle prof. dr. Jiřiny Popelové, in Jiřina Popelová, filozofka a učitelka filozofie, Brno: FF UJEP 1984, s. 20.

6 Ivana Holzbachová, Historie a čas, in tamtéz̆, s. 27. 
v době nástupu buržoazie v západní Evropě. “7 Podle Pavla Flosse patřila Popelová k těm, kteří dokázali, „že velikost Komenského pedagogiky je dána smělostí jeho filozoficko-sociálního myšlení“. ${ }^{8}$ Cenná jsou také zjištění, která Popelová jako znalkyně italské renesance přinesla při analýze vlivu renesanční filozofie (Marsilio Ficino, Pico della Mirandola, Tommaso Campanella), M. Kusánského a machiavelismu na myšlení Komenského. Už před válkou věnovala Popelová pozornost řadě svých současníků i učitelů - K. Vorovkovi, V. Hoppemu, ${ }^{9}$ V. Úlehlovi, za války pak F. Krejčímu (Filozof František Krejčí, 1942). Ve Studii o současné české filozofii (1946) podává zejména portréty Josefa Tvrdého a J. L. Fischera, ale také I. A. Bláhy, Jiljího Jahna a dalších.

Z pražské konference v roce 2004 vydala Filozofická fakulta Univerzity Karlovy v roce 2005 sborník pod názvem Filosofka Jiřina Popelová..$^{10}$ Obsahuje především vzpomínkové statě (Vladimír Justl, Ivo Tretera, Jaroslav Kota ad.), ale řada autorů se věnuje i pracím a filozofickým aktivitám Jiřiny Popelové. Jiřina Šiklová připomíná její životní osudy. Přežila dvě světové války, žila ve dvou totalitních režimech a byla ve svých očekáváních opakovaně zklamávána.

Většinou tvoří Velké dějiny pozadí našeho života, pozadí, které jsme si nevybrali, které musíme přijmout a jemuž se musíme přizpůsobit, chceme-li přežít. ${ }^{11}$

Jaroslava Pešková se zamýšlí, proč se Jiřina Popelová v některých svých textech (např́klad v systémové části Etiky) nekriticky ztotožňovala s ideologickými klišé, a domnívá se, že to plynulo z jejího aktivistického pojetí dějin a z toho, že „nepochopila relativnost (relačnost) rozhodování o tom, co je pozoruhodné, co je hodnotou“. ${ }^{12}$ Pro Peškovou je Popelová představitelkou kontextuálního pojetí světa, které je typické pro ženský pohled.

Dílo filosofky Jiřiny Popelové je tak průzorem do dění dějin minulého století z úhlu pohledu ženy, která se musela vyrovnat s oběma válkami, s protikladem

7 Olga Loužilová, Obraz J. A. Komenského v díle Jiřiny Popelové, in tamtéž, s. 76.

8 Pavel Floss, Ke komeniologické práci Jiřiny Popelové, in tamtéž, s. 78.

9 Po Hoppeově smrti usilovala společně s brněnským Hoppeovým žákem Robertem Konečným o vydání hoppeovského sborníku (jak ukazuje níže zveřejněná korespondence z let 1931-1936), ale sborník se nakonec vydat nepodařilo.

10 Filosofka Jirina Popelová, ed. E. Foglarová, Praha: FF UK 2005, 109 s.

11 Jiřina Šiklová, Sto let od narození profesorky Jiřiny Otáhalové-Popelové, in tamtéž, s. 8.

12 Jaroslava Pešková, Zamyšlení nad dílem Jiřiny Otáhalové-Popelové, in tamtéž, s. 11. 
touhy po pozitivní realizaci ideálních sociálních hodnot a realitou moci v dějinách. ${ }^{13}$

Milan Sobotka a Dušan Prokop chápou Jiřinu Popelovou jako filozofku kultury. Milan Sobotka upozorňuje, že už prvotina Popelové Poznáni kulturní skutečnosti předznamenala $\mathrm{v}$ tomto smyslu další její práce. Zde i v pozdějších textech „Popelovou tedy zajímá filozofie jako součást širší struktury kulturní tvorby“. ${ }^{14}$ Popelová ve svých komeniologických studiích i textech k dějinám filozofie postupuje od širšího společenského a kulturního rozboru k vlastní analýze filozofického stanoviska. Byla si dobře vědoma, že „filozofie a její dějiny nejsou prostě jen dějinami názorů a jejich systémů, ale že jsou součástí širšího celku - kultury“. ${ }^{15}$

Za nejvýznamnější práce Jiřiny Popelové jsou pokládány Tři studie z filozofie dějin, Cesta J. Á. Komenského k Všenápravě a Rozpad klasické filozofie. ${ }^{16}$ Právě Rozpad klasické filozofie představuje její vrcholnou práci z dějin evropské filozofie. Popelová se v ní věnuje filozofii 19. století, kterou charakterizuje kategorií porevoluční myšlení. Jejím podstatným znakem je vnitřní antagonismus scientismu a iracionalismu a toto schizma umožňuje historicko-filozoficky uchopit moderní myšlení 19. a 20. století. Popelová odmítla Lukácsovu tezi z jeho práce Zerstốrung der Vernunft o zničení rozumu, o totální iracionalizaci buržoazního myšlení, o jeho lineární degradaci a obsahovém vyprazdňování. Dokázala svým citlivým přístupem ocenit jeho podněty a hodnoty, překonat schematismus pohledy do charakteru epochy a do vnitřní povahy porevoluční filozofie. Ukazuje to i její př́ístup k Friedrichu Nietzschovi. To, že se Jiřina Popelová Nietzschem zabývala, není překvapující. Autorka, která se obsáhle věnovala problematice etiky, axiologie a filozofie kultury, nemohla pochopitelně kolem Nietzschova díla přejít bez kritického povšimnutí. Řadí Nietzscheho do druhého období porevoluční etapy buržoazní filozofie, charakterizuje ho jako určitý typ iracionalismu 19. století. Je historičkou filozofie, podává obraz Nietzschova života, periodizuje jeho dílo a vykládá obsah jednotlivých etap. Hledá u něho, podobně jako jiní autoři, systém, za jehož pojítko pokládá Nietzschovo pojetí vůle k moci. Připomíná však Nietzsche-

13 Tamtéż, s. 11.

14 Milan Sobotka, Jiřina Popelová - filosofka kultury, in Filosofka Jiřina Popelová..., s. 20.

15 Dušan Prokop: Filosofie kultury Jiřiny Popelové, in tamtéž, s. 23.

16 Srov. např. Jiří Gabriel: Jiřina Popelová jako komentátorka a historička české filozofie, in Jiřina Popelová, filozofka a učitelka filozofie, s. 33. 
ho jako myslitele, který kolísal mezi estetismem a biologismem. Na rozdíl od jiných dřivějších i tehdejších interpretací jednak Popelová nepokládá „pozitivistické“ etapy v Nietzschově vývoji za nějaké omyly na filozofově cestě, nýbrž za fáze zákonité, jednak klade důraz na etapu poslední, období po Zarathustrovi, které charakterizuje jeho návrat k pozitivismu a jeho překonání „biologickým naturalismem a pragmatickým perspektivismem“. ${ }^{17}$

Popelová je k Nietzschově filozofii, která je podle ní plná rozporů, kritická, nepomíjí jeho vlivy záporné v dosahu společenském a politickém. Svými analýzami však tvoří „Nietzsche významný článek v pojímání kultur jako smysluplných, uzavřených celků, s organickým cyklem jarního rozkvětu až k podzimnímu uvadání. Je citlivým analytikem ranních, poledních i podvečerních kulturních atmosfér". 18

prof. PhDr. Jan Zouhar, CSc.

Katedra filozofie, Filozofická fakulta, Masarykova univerzita

Arna Nováka 1, 60200 Brno, Česká republika

zouhar@phil.muni.cz

17 Jiřina Popelová, Rozpad klasické filosofie. Praha: Svoboda 1968, s. 272. Srov. Jan Zouhar, Jiřina Popelová a Friedrich Nietzsche, in Jiřina Popelová, filozofka a učitelka filozofie, Brno: FF UJEP 1984, s. 99-101, cit. s. 100.

18 J. Popelová, Rozpad klasické filosofie..., s. 272-273. 
